\title{
The road to a free market- law, legislation and the entrepreneurship
}

\author{
Ligia Munteanu, “Alexandru Ioan Cuza” University of Iasi, Romania
}

\begin{abstract}
The development of a country depends on the legal system of that country. Romanian aconomy haw knoweded, as many states, different ideologies and govemental methods, the segnificant difference beetween then being the degree of state interventionism in the economy. To obtain a free market, we need a proper legal system, a special guvernmental attitude and a good implementation of the state of law principles and democracy. As we feel the need of change, the state tries to come with new programs and perspectives. The result is a legislative inflation, that scares any antreprenorial initiative. But there is another way of forming new institutions or changing them, more appropriate to the market. This is the way based on practical experience, tradition and responsability.
\end{abstract}

\section{Keywords}

free market, law, legislation, institutions, entrepreneurship.

JEL Codes: D40, K10, K20, K23

\section{Introduction}

„The power corrupse, and absolute power corrups in an absolut way" -these were the words of Lord Acton, reffering to the relation betwen state and economy in the United Kingdom sometime in the XVIIth century. If today, those who lead us, would have in mind these words, maybe it wouldn't be so easy any more to speak of the same objectives and advices.

Along history, the sates experienced many ways of organising the society, from absolutism to socialism, communism, than liberalism, until the democracy witch everybody seems to adopt in our days. These ears are a great experience to learn from. It should give us a general view on what interventionism ment, its effects on social life and on progress itself.

The economic is realy important in tranfomation. Tranzactions, commerce, economic interest, all these were vectors of the most tragical wars but also the reason for the great unifications. Even the European Union was buil on the Community of Cold and Steel, a small sector, but vital enough to become more important than the nationalistic ambitions of Germany and Frace.

Looking over the different periods in history, a question appears to seek for its unswer. Whitch model was best, witch is the most apropriate for economic development, if it is one? In fact, the question is, which of them is able to offer that „whealth of nations”, Adam Smith was writing about. So, how much state does the economy need?

Keynes, even thoough he didn'tlike the state in its nature, is forced to recognise it's active role in economy, in order to resolve the chrises of the time. And in short run, in worked, but on longer orientation, the effects of keynesian measures were not actually as predicted. Marx and Lenin cammed with the philosophy of the „unique manual”-a single party, a single orientation. These doctrine not only it didn't lead to progess, but it distroied the realy promising projects and determined a path dependency as strong as it is unwished, that marks the ex-socialist countries even today. 
Liberalism, aplaused by great names like Mises, Hayek, has woken up the world and the economic spirit. Their proposal was a perfect capitalism, were rules are made by competition and efficiency. This was a world in witch the state was far enough from the market, the market is free, an alive institution, capable of rewordng those who deserve it and capabe of rejecting the ones that are not productive. A world leaded by the invisible hand of Adam Smith. The image of these world is the dream of any economist and their objective. Reality thow puts us infront with a strong state, that even in the most liberal countries, knows how to make itself present.

\section{Liberty and constraint}

To see the role of the state in the economy, we need to focuse first on two key concepts, that are measurement factors in our case, liberty and coercition. First of all, these terms ar legal ones, but

hey are used in every domain. The law, the implementation and protection of teh law is one of the most important atributes of the state, beeing both neccesary and obligatory. In fact, the implications of the state in the economy are bassicly related with the legislative programe.

Secondly, becouse few economist are concerned with law, as few law practicians read economic books, the two concepts have different definitions in these domains ${ }^{1}$. This is unjustified, because we cannot speak of a free market if we don't have legislative relaxation, as well as economic coerciveness is realized by legal norms.

The definition of liberty is essential, because many times different people use this word in much other significance as the real one. The concept of liberty that will be used in this paper is the one linked with the economic entrepreneurial spirit, as Lord Acton, in the beginning of his "History of Liberty" defines it: "By liberty I mean assurance that every man shall be protected in doing what he believes to be his duty against the influence of authority and majorities, custom and opinion" 2 . In other words, he meant the liberty of the entrepreneurial individual to decide upon his production, upon contracts, negotiations and selling points. From here is will emerge the difference between different agents, some of them taking smarter decisions than others, measured in profit and market share. These are the meaning of liberty in the market economy, competitiveness in essence, and not the meaning often cried out by politicians who learned the trick of wrong interpretation of the democratic principles.

To understand better what liberty is, the term must by analyzed in comparison with its opposite- constraint. Between these two there is a strong bond, sometimes one being confused with another. There are cases in which constraint is wanted, as in the case of the Russian soldiers, which used to say they liked life in the army, because it turned out to be a commended ideal. And for sure there are many cases similar to this one, with individuals that carry out these kinds of sentiments, in different situations. Aristotle was the first to divide people in two categories: the ones made to rule and those that must be ruled.

But even if some like constraint, it will be an abuse to consider this liberty. And this is because no one can be free from others if the later ones are free to constrain the first. In other words, everyone is "free" if he can constrain in some way other people to refrain from constraining him in some respect ${ }^{3}$.

In this sense, "freedom" and "constraint" are inevitably linked, and this is probably too often forgotten when people speak of "freedom." In economics, this play with words has great importance in understanding the attitude of the state regarding the market. As long as the state decides in the market, both will find them in a vicious circle. A, action of the state will constrain the market in some way, even if many times these is made in the name of freedom.

\footnotetext{
${ }^{1}$ Leoni,B.(1991), Freedom and the Law, Indianapolis, Liberty Fund, p.10

2 Acton, Lord (2001), Despre libertate, Editura Institutul European, p.13

${ }^{3}$ Leoni,B.(1991), Freedom and the Law, Indianapolis, Liberty Fund, p.36
} 
The market, in its turn, will come in difficult situation, constraining the state to interfere again, creating a new cause-effect cycle. The phenomenon appears as well because the decisions of the leaders are in most of the cases wrong for the market, doing more bad than good, because they are realized on short run and rarely in long oriented term, or based on superficial and false analysis.

An ideal form of constraint would be if the market could constrain the state to adopt a lessefaire attitude. In this system, the power will be in the market, economic principles being the ones that would lead the way and not some ordinary legislation. Competition also involves that a part will lose, and that is many times wrong understood. To avoid social moves, the state sometimes tries to help all, and intervenes in the market. And it does so because it has in his hands the most powerful weapons to do so: legislative and executive power. The market does not have that. Unfortunately, the state decides what the market does through jurist. They want to dictate the road of commerce.

The law is and it will remain the most important force of the state, the base of a society. Willing or not, the companies must adapt to the national and international law, to survive. The question arises now upon the correctness of the legal system.

A significant difference is between law and legislation, after adopting the Napoleon Code. We can distinguish between the laws of traditions, the common law as it is named in England, the law raised from natural experience, in the court, in front of the judge, from the legal processes of the Romans until the complex situations of today. "The difference is the direct consequence of an empiric vision on the world in England and a rational one in France". One finds the essence of liberty in spontaneity, the other believes in a collective absolute followed project. One is for slow, organic growth, the other for premeditation; one is for a procedure of attempt and error, the other for imposing one single valuable model. The second was also the origin of totalitarian democracy"4.

So in the first model the jurisprudence gains importance, the customs are respected; the moral and the judgeless are realized in the name of equity, and not in the name of law. In the second, the laws are not created as a result of the needs on the market, but proposed by some illuminated minds. So new norms appear, apparently in a flexible and adaptive system, but in reality they are far away from the necessities of the individuals, carrying just for the interest of some small forum. More than that, the economic agents have different rules in the morning as they had in the evening, tariffs, obligations that suffocate them.

This is not something new, or as we could say at a first look a system characteristic to the developing societies. In their papers, authors like James Burnham in the United States of America, professor G. W. Keeton in England and also F.A. Hayek complain about the weakening of the legislative tradition power of the American Congress and the passiveness of the English Parliament, caused by the more and more frequent legislative delegations of the executive.

As well in Romania, we can speak of a massive legislative inflation, thousands of norms that complicate the activity of the companies and block the national Parliament.

Another trough is the human nature. Governors are human, and many with strong economic interests. Some laws can be accused of having specified, limited and closed objectives. The paradox of the world we live in is that we are ruled by people, and not by the fact that "we are". Machiavelli himself would have failed imagining such a great apparatus of dignifying the will of men and to honor the will of some Tiran taking decisions in the protective sphere of the law made by him. We pay tribute to the roman and to the English system of law, but we forget what they meant.

The historical experience makes us able to be sure about the effects of the communism, totalitarism, socialism in any form. But, without entering in a political discussion, we should observe the system of the representative democracy. By personal vote, individuals choose a

${ }^{4}$ Hayek, F.A.(1998), Constituţia Libertății, Iaşi, Institutul European, p. 79 
candidate. But never the whole population will choose the same man. The results of the elections, for a part of the people will mean a loss. Democracy seems in this way unfair, because those who choose something else are forced to obey the rules of the interest of others. Liberty of expression is guaranteed, but not that of action.

The conflict seems to be in a double way. First of all, as Mises said ${ }^{5}$, an economy ruled by a hand of leaders will surely collapse. Never some men gathered around a table, can know the correct prices, relations, the needs of the productions and consumers, the realities of the market. You have to be in the market to observe that, to feel it. They only can take some measures, they think of taking into considerations the first bad signs of the economy without leaving to the market the job to adjust itself. So even chosen ones can fail in respecting the interests of the citizens that voted them. Secondly, those who had different opinions have no way but to apply the new norms. The result is that economic agents find different ways of hiding the real numbers, and here comes the underground economy, the black market, simulated contracts, and corruption.

It seems that Hobbes was right speaking about the "war of all with all" when he referred to the property rights and individual liberty. The knowledge of the rules is ignorant in $99 \%$ of what is going on around.

Taking just a small example from the Romanian experience, let's make references to the laws of tariffs and taxes. As many governments, as many norms were there in this field, each one striking right in the hard of the small and medium producers. The solution implicated is again, from the individual perspective, that of hiding the numbers. The real profit is known only by the manager. Isn't this destructive economy? How can this become a free market?

So there is more than an analogy between free market and the judiciary law that of the judges, just as there is more bound between planned economy and legislation. In the past, the most powerful economies were those of the Roman Empire and of the Anglo-Saxon territory. Respected tradition, jurisprudence, habits and customs, moral rules respected by everyone. In the roman time, even the translation of property was made in front of the judge without any manuscript. Could it be possible today to make a transaction without a written contract? Isn't this feeling of fear and reticence in the market taken from all these brutal interventions from the state?

\section{Free market, law and responsibility}

As in state as in the market we must not forget about the human nature. It is true the presumption of Professor Hayek, that individual knowledge is the most healthy and efficient for the economy. Only individuals know what to do and how to decide on the market, what they need to change in the production and that customers need at what prices, when to invest and when to restrain the activity. But the same great economist recognizes the instability of human nature, ruled by feelings, not always honest and correct. So there is a need of general principles, known and respected by all to become imposed for the good of the society. People must know if they do wrong they will pay for their acts.

A free market must not confuse opportunities with opportunism and economic growth with avarice. In this since we need law, not legislation, but law. Not orders, but laws based on the good principles of the state of law as they were formulated at the origins.

The states that evolved to the state of law can be classified in two categories. First of all, are those in which the transformation happened in time, in a natural way, combining practices and morality with habits and customs? From here were formulated and written the legal principles. It is the example of the British experience, "that offers us an interpretation of a civilization growth that constitutes even today the indispensable base of the argument in

\footnotetext{
5 Mises, von L.(1949), Human Action: A Treatise on Economics, New Haven: Yale University Press,p.305
} 
favor of liberty" ${ }^{6}$. The British vision is expressed of the "way in which the nations stumble themselves by institutions created a result of human action, and not the execution of a human project" $"$.

Secondly there are the countries that turned to the state of law in a violent way, a drastically movement from the last system, copying the democratic principles without a solid base. The institutionalism demonstrated that the old decisions still order the way we act in present. So the past still has its imprint on our system. The path dependency gives birth to that hybrid combination of democracy, state of law and social or totalitarian practices.

The change is difficult but not impossible. At the basis of success stands responsibility, of the government for the society, of the jurists in front of justice, of the economic agents of the market. All together become the responsibility of building a sold future for the society, a strong economy, an efficient legal ground, correct and proper institutions.

These institutions we refer at are gowned from the daily practice, from the needs of the market. They are not invented by rulers. From the efforts of individuals, it can grow up something that will always be better that the products of some minds, an emergence of an order as a result of the evaluation and practice ${ }^{8}$.

A free society needs that state functioning for the people, by the people and with the people.

The law must be arranged around the general principles, must be natural not imposed, not created. It must be the written form of the customs everyone already acts by. The law must sustain the free market and not compete with it. This should be the role of the state. To be not the guardian of the economy, but the guardian of observed institutions and experienced and from them to complete the law if necessary.

The law should be general; a norm should be applicable to most of the situations and in the name of equity. One of the leaders of liberalism intellectuals of the XIXth century, Benjamin Constant, indicates the problem with the correct words describing liberalism as: "systeme de principes". 9 A free society means not only that the whole governmental action is ruled by principles, but there is an ideal accepted as supreme principium, that governs over all legal acts and norms.

This means responsibility. The government must permit people to feel both opportunity and wrong option, so they can become responsible as well. In modern times, the feeling of responsibility was weakened by the confidence that the state must help us anytime, that it must offer us a good living, a successful economy, subventions, social money, etc. So it offers a protective umbrella that eliminates the entrepreneurial competitive spirit.

The economic agents support themselves because they are capable of following with success their plans, conforming often to a general model of doing things. They prove a regularity in actions that is not the result of command or constraint, but of a common sense and of a habit firmly recognized. The free market should be in dialogue with the state. Even if strong, the market also suffers from uncompetitive practices, frauds and abuses. Here comes the need of a vertical state, indifferent to individual interest and capable of imposing the law to be respected. Respecting general principles must mean sometimes constraint to those that make abuses. They are not seen from the state as abusers, but from the rest of the economic agents in the market. So constraint can only be limited if there is a high degree of voluntary recognition of rules for all. There is also a benefit. In time, survive only the best rules, so change also comes in a natural way in law.

\footnotetext{
${ }^{6}$ Hayek, F.A.(1998), Constituţia Libertăţii, Iaşi, Institutul European, pag.89

${ }^{7}$ Ferguson,A. (1767), An Essay on the History of Civil Society, Edinburgh, p.187

${ }^{8}$ Menger,K. Untersuchungen, Cartea III pp.163-165 apud. Hayek,F.A.(1991), Constituţia libertăţii, Iaşi, Institutul European, p. 103

9 Constant, B.(1874), “Despre arbitrariu” in Oeuvres politique de Benjamin Constant, Ed.Louandre, Paris, 1874, p.91-92
} 


\section{Conclusions}

The development of a society is strongly bound with the development and prosperity of the economy. And this is more likely to exist as we approach and tend to a free market, with a free society. The state is fundamental in this construction. Any activity, most of all in economics, must adjust with the law. If the legal system suffers from inequity, the whole society will do so. They way norms appear, implemented and respected tells almost everything of the degree of liberty in a society and in the market.

For the question how mush state does the economy need, the answer is simple: the free market is called free because it should be that way So no interventionism in the economic field, as tempting it may be. The need for the state is in another place. And that is to assure that the economy is left alone. Governments must not be a machinery of laws but an expression of the respect of the fundamental rights and liberties for the citizens.

Following personal interests, or simply from ignorance, sometimes the state derogates from its purpose, makes abuse of the legislative power it has and goes over the market imposing some norms reasoning the action with "reasons of state". This is the greatest offence for the society. In this position, the state appears very high in the top, far away from common ignorance, knowing exclusively solutions and therefore throwing them for implementation, apparently inexplicable for all. The expression "reasons of state" is the simplest way of doing what they want without giving any explication and also convincing you that this is the right thing to do.

Individuals, used to these practices, feel free to blame the state for the failure. The economic agents don't look for answers in the market; they wait for help from the state, because they think if it created the damage, it must be the one who makes things write again. And again there is interventionism, until the next moment of impasse.

If I could understand in some way the meaning of the formula "reasons of state" in the domain of national security, I don't see how it can be present in the economic decisions. It is only an abuse. Actually, whose reasons are those? What mean those reasons? Aren't the leaders sent there by the people, for some program they declared in the elective campaign? So ones at the leading table, they do not become independent, they are most of all meant to represent the interest of the citizens. So the reasons they should claim are, logically, the ones of the citizens. Or they should be. The attitude of using that formula and interfering in the market has no logical sense ever. A market can never survive if in some occasions, benefits are given from restraining liberty.

The economy does not need the state, but the society needs good institutions. These also must not be organized by the state. They should be raised from necessities, comprising the needs of the market, in time, from tradition, from the efforts of individuals.

The medium in which the free market acts is limited by laws. The state should make sure that these laws do not impose anything on the market but the general principles recognized by all, that these laws sustain the, market, like a solid ground without changing its directions.

We are today in an era of democracy, state of law, open economy, but I must say that we have much to learn until we truly implement these principles. A free market, a free society is not a simple objective, and neither can it be opened in short time, but it is important to choose the correct road to it.

"Nothing is more fertile in accomplishments then the art of being free; but also nothing is more difficult than this obedience of liberty. [...] In general, liberty is instituted, in a difficult way, in the heart of storms; it is defined in times of civil Discordia; and its benefits can only be appreciated at an older age". 


\section{Studies and Scientific Researches - Economic Edition, no. 15, 2010}

\section{Bibliografy}

1. Acton, Lord (2001), Despre libertate, Ed. Institutul European

2. Bastiat, F. (1946), Selected Essays on Political Economy, New York: D. Van Nostrand Co.

3. Buchanan, J. (1954), "Individual Choices in Voting and in the Market" Journal of Political Economy, London

4. Constant, B.(1874), "Despre arbitrariu" in Oeuvres politique de Benjamin Constant, Ed.Louandre, Paris

5. Ferguson,A. (1767), An Essay on the History of Civil Society, Edinburgh

6. Hayek, F.A.(1998), Constituția Libertății, Iaşi, Institutul European

7. Hayek, F.A.(1979), Law, Legislation and Liberty, The University of Chicago Press

8. Holdsworth,W.S. (1924), A History of English Law, V, London

9. Leoni,B.(1991), Freedom and the Law, Indianapolis, Liberty Fund

10. Mill,J.St.(1994), Despre libertate, Bucureşti, Humanitas

11. Mill,J.St.(1982), Considerations on Representative Government, NY: Henry Holt\&Co.

12. Mises, von L.(1949), Human Action: A Treatise on Economics, New Haven: Yale University Press

13. Schultz,F.(1946), History of Roman Legal Science, Oxford: at the Clarendon Press, 1946

14. www.econlib.com 